\title{
Kepuasan Ibu Hamil atas Layanan Konseling Gizi di Wilayah Kerja Puskesmas Jatinangor
}

\author{
Kiki Sundari ${ }^{1}$, Sefita Aryuti Nirmala ${ }^{2}$, Irna Kurnia Aprillani ${ }^{3}$, \\ Raden Tina Dewi Judistiani ${ }^{4}$, Puspa Sari ${ }^{5}$ \\ Program Diploma IV Kebidanan, Departemen Ilmu Kesehatan Masyarakat \\ Fakultas Kedokteran, Universitas Padjadjaran 1,2,3,4,5 \\ kikisundari09@gmail.com ${ }^{1}$
}

Diajukan 30 Maret 2019 Diperbaiki 20 Mei 2019 Diterima 19 Agustus 2019

ABSTRAK

\begin{abstract}
Latar Belakang: Kekurangan gizi pada ibu hamil dan bayi telah menyumbang setidaknya 3,5 juta kematian setiap tahun. Konseling mengenai pentingnya pemenuhan gizi selama kehamilan sangat perlu dilakukan sebagai upaya promotif dan preventif pelayanan kebidanan. Kepuasan pasien adalah salah satu indikator keberhasilan pelayanan konseling gizi. Kepuasan sendiri bersifat subjektif dan merupakan hasil reaksi afeksi yang sangat ditentukan oleh karakteristik individu, seperti pendidikan, umur, dan pekerjaan.

Tujuan: Menganalisis karakteristik ibu, kepuasan terhadap layanan konseling gizi secara umum dan khusus berdasarkan lima dimensi kepuasan, dan frekuensi karakteristik responden terhadap tingkat kepuasan secara umum di wilayah kerja Puskesmas
\end{abstract}

Jatinangor.

Metode: Penelitian menggunakan metode penelitian deskriptif dari data primer dengan jumlah responden yang digunakan sebanyak $77 \mathrm{ibu}$ hamil yang diambil dengan caraaccidental sampling, analisis data menggunakan univariat.

Hasil: Hasil penelitian menunjukkanmayoritas ibu hamil berusia $20-35$ tahun $(81,81 \%)$ dengan tingkat kepuasan $72,73 \%$, pendidikan terakhir SLTA (48,05\%) dengan tingkat kepuasan $41,56 \%$, dan mayoritas tidak bekerja $(83,12 \%)$ dengan tingkat kepuasan $71,43 \%$.

Kesimpulan: Secara umum 88,31\% ibu mengatakan puas, $48,05 \%$ ibu puas pada dimensi tangibles, dan $100 \%$ ibu puas berdasarkan empat dimensi lainnya.

Kata Kunci: ibu hamil; konseling gizi; kepuasan

\section{ABSTRACT}

Background: Malnutrition in pregnant women and infants has contributed to at least 3.5 million deaths every year. Counseling on the importance of fulfilling nutrition during pregnancy is very necessary to be carried out as a promotive and preventive effortby midwives services. Patient satisfaction is one indicator of the success of nutrition counseling sevices. Satisfaction is subjective and the result of an affective reactionby characteristics of mothers based on reproductive age, education, and occupation.

Objective: This study aims to identify characteristics of mothers, satisfaction with nutrition counseling services provided by midwives in general and specifically based on five dimensions of satisfaction, and frequency of respondents' characteristics of satisfaction levels in general in the work area of the JatinangorPrimary Health
Care.

Methods: The research method used was descriptive from primary data with the number of respondents participated was 77 pregnant womentaken usingaccidental sampling, data analysis used was univariate.

Results: The results of the study showed a majorityof pregnant women age 20-35 years (81.81\%) with a satisfaction rate of $72,73 \%$, senior high school graduates $(48.05 \%)$ with a satisfaction level of $41.56 \%$, and the majority do not work $(83.12 \%)$ with a satisfaction rate of $71.43 \%$.

Conclusion: In general, 88,31\% of mothers said they were satisfied, $48,05 \%$ mothers were satisfied on the dimensions of tangibles and $100 \%$ mothers were satisfied based on the four another dimensions of satisfaction.

Keywords: women; nutrition counseling; satisfaction. 


\section{PENDAHULUAN}

Angka Kematian Ibu (AKI) di dunia masih cukup tinggi. Sekitar $830 \mathrm{ibu}$ meninggal akibat komplikasi terkait kehamilan dan persalinan setiap harinya. Sebanyak $303.000 \mathrm{ibu}$ meninggal selama dan setelah kehamilan dan persalinan pada tahun 2015(WHO, 2016).

Sustainable Development Goals (SDGs) sebagai kelanjutan dari Millenium Development Goals (MDGs) merupakan upaya yang dicanangkan oleh United Nation dengan salah satu target, yang tercantum dalam poin ketiganya yaitu Good Health and Well Being yang berupaya menurunkan rasio kematian ibu global hingga kurang dari 70 per 100.000 kelahiran hidup pada tahun 2030 (United Nations, 2015).

Salah satu penyebab tidak langsung tingginya AKI adalah status gizi ibu hamil yang buruk. Kekurangan gizi pada ibu hamil dan bayi telah menyumbang setidaknya 3,5 juta kematian setiap tahunnya dan memberikan konstribusi sebanyak $11 \%$ dari jumlah penyakit global di dunia(Prawita, Susanti, \& Sari, 2017).

Kurang Energi Kronik (KEK) merupakan manifestasi dari kekurangan gizi buruk dan menjadi salah satu masalah di negara berkembang (Prawita, et al., 2017). Pada tahun 2013, didapatkan sebesar 24,2\% ibu hamil umur 15-49 tahun dengan LILA $<23,5 \mathrm{~cm}$ (berisiko KEK) di Indonesia dan 20\% di Jawa Barat (Kementerian Kesehatan, 2013). Sementara itu, 15,7\% ibu diketahui mengalami KEK di Kabupaten Sumedang (Depkes, 2007). Dampak dari kondisi ini adalah meningkatnya risiko kematian ibu, anemia, perdarahan pada trimester tiga, persalinan memanjang, dan perdarahan postpartum(Purandare, 2012).

Anemia merupakan masalah gizi pada kehamilan selain KEK yang juga menjadi penyebab tidak langsung perdarahan postpartum sebagai penyebab utama tingginya kematian ibu(Mariana \& Khafidhoh, 2013).

World Health Organization (WHO) menjelaskan bahwa anemia mempengaruhi hingga setengah miliar wanita usia reproduksi di seluruh dunia. Pada tahun 2011, WHO melaporkan prevalensi anemia sejak tahun 1995 hingga 2011 mengalami penurunan yang berarti, dari $43 \%$ menjadi $38 \%$ (3,4 juta) pada ibu hamil. Namun pada tahun 2012, WHO kembali memperkirakan angka anemia pada ibu hamil di dunia mencapai $41,8 \%$, dimana $48,2 \%$ diantaranya terjadi pada ibu hamil di Asia (WHO, 2012). Sekitar 37,1\% ibu hamil di Indonesia menderita anemia pada tahun 2013 (Riskesdas, 2013). Dalam profil kesehatan Kabupaten Sumedang tahun 2017, ditemukan $8,5 \%$ ibu hamil dengan anemia (Dinas Kesehatan Sumedang, 2017), sedangkan di Kecamatan Jatinangor ditemukan 21,9\% ibu hamil dengan anemia dari 105 ibu yang dilakukan skrining dengan metode CBC (Susanti et al., 2017).

Kemenkes RI memaparkan, bahwa kondisi anemia pada ibu hamil dapat memberikan dampak yang serius baik pada ibu maupun janin, berupa meningkatnya frekuensi risiko mortalitas dan morbiditas maternal, keguguran, rendahnya imunitas ibu dan bayi yang dapat memudahkan keduanya untuk terkena infeksi, angka prematuritas, BBLR, dan angka kematian perinatal pun meningkat (Sudikno\& Sandjaja, 2016).

Penyebab utama permasalahan gizi dalam kehamilan khususnya KEK dan anemia dikarenakan oleh pola makan ibu hamil seharihari yang rendah dengan nutrisi, sebagian besar terdiri dari nasi dan menu yang kurang beraneka ragam (Sulastijah, DW, \& Helmyati, 2015).

Konseling mengenai pentingnya pemenuhan zat gizi selama kehamilan sangat perlu dilakukan sebagai upaya promotif dan preventif melalui edukasi dan konseling, untuk meningkatkan pengetahuan dan kemampuan ibu hamil, khususnya mengenai pemenuhan kebutuhan zat gizi selama masa kehamilannya. Penelitian Wardle et al,(2004), menunjukkan bahwa pengetahuan gizi yang baik berhubungan signifikan dengan pola makan yang sehat (Amalia, Permatasari, Ali Khomsan, Herawati, \& Nurdiani, 2015). Pendidikan gizi dalam bentuk konseling dapat meningkatkan 
skor pengetahuan gizi dan sikap pada ibu (Azzahra \& Muniroh, 2015).

Kepuasan ibu hamil terhadap konseling gizi pun menjadi sebuah output yang perlu dievaluasi untuk pada akhirnya dapat dinilai apakah ibu puas, paham, mengerti dan merasa bahwa informasi yang disampaikan dapat bermanfaat atau tidak (I, Kullen, Burdon, \& $\mathrm{H}, 2014)$.

(Utama, 2003) menjelaskan bahwa kepuasan sendiri bersifat subjektif dan merupakan hasil reaksi afeksi (penilaian perasaan), meskipun objek yang dinilai adalah sama. Reaksi ini sangat ditentukan oleh latar belakang atau karakteristik individu, seperti suku bangsa dengan nilai budaya yang dianut, pendidikan, umur, jenis kelamin, pekerjaan, status perkawinan, atau pendapatan (Kurniawan \& Intiasari, 2012).

\section{METODE}

Penelitian ini menggunakan metode penelitian dengan desain deskriptif untuk menggambarkan tingkat kepuasan ibu hamil atas layanan konseling gizi yang diberikan bidan. Data yang digunakan adalah data primer yang dikumpulkan melalui pengisian kuesioner. Penelitian ini dilakukan di 7 desa wilayah kerja Puskesmas Jatinangor, kecamatan Jatinangor, Kabupaten Sumedang, yaitu Desa Cibeusi, Cikeruh, Cipacing, Sayang, Hegarmanah, Cilayung, dan Cileles yang pelaksanaannya dilakukan pada bulan Juli hingga Agustus 2018.

Populasi kurang lebih sebanyak $319 \mathrm{ibu}$ hamil, dengan pengambilan sampel menggunakan metode accidental sampling pada saat program screening anemia yang diselenggarakan oleh Fakultas Kedokteran Universitas Padjadjaran dengan berkolaborasi bersama bidan desa dalam pemberian konseling gizi yang sebelumnya telah diberikan pelatihan konseling gizi, yaitu dengan sampel sebanyak 77 orang ibu hamil.

Kriteria inklusi dalam penelitian ini adalah ibu hamil normal yang mengikuti kegiatan screening anemia, ibu hamil yang berdomisili di wilayah kerja Puskesmas Jatinangor, ibu hamil yang bersedia dijadikan sebagai responden, dan ibu hamil yang telah mendapatkan konseling gizi. Kriteria eksklusi yang digunakan adalah ibu hamil dengan riwayat diabetes mellitus dan/atau tuberculosis.

Pengumpulan data diambil setelah responden membaca dan mengisi informed consent, responden mengisi kuesioner yang berisi pernyataan terkait kepuasan responden yang terdiri dari beberapa dimensi kepuasan yaitu Keandalan, Tanggung Jawab, Kepastian, Empati, dan Keberwujudan. Kuesioner tersebut terdiri dari 27 pernyataan. Dimensi Keandalan diwakili 5 pernyataan, Tanggung Jawab, Kepastian dan Empati masing-masing diwakili 6 pernyataan, dan Keberwujudan diwakili oleh 4 pernyataan yang selanjutnya dinilai dengan menggunakan skala likert yang terdiri dari 3 skor yaitu skor 0 (tidak setuju), skor 1 (setuju), dan skor 2 (sangat setuju) yang kemudian diklasifikasikan menjadi puas jika skor $\geq$ nilai median dan tidak puas jika skor $<$ nilai median.

Analisis data yang digunakan yaitu univariat dengan perangkat lunak (Ms. Excel), kemudian disajikan dalam bentuk tabel untuk menggambarkan karakteristik ibu berdasarkan usia reproduktif, pendidikan, dan pekerjaan, serta melihat gambaran kepuasan ibu hamil terhadap layanan konseling gizi yang diberikan oleh bidan secara umum dan khusus berdasarkan 5 dimensi kepuasan di wilayah kerja Puskesmas Jatinangor tahun 2018.

Penelitian ini sudah mendapatkan ijin penelitian dari komite-etik Fakultas Kedokteran Universitas Padjadjaran dengan nomor register 686/UN6.KEP/EC/2018.

\section{HASIL DAN PEMBAHASAN}

\section{A. Karakteristik Responden}

Karakteristik Ibu hamil dalam penelitian ini meliputi usia reproduktif, pendidikan dan pekerjaan Ibu hamil. Hasil penelitian menunjukkan proporsi antara responden pada rentan usia reproduktif sehat (20-35 tahun) dengan reponden yang berusia 
$<20$ tahun dan atau $>35$ tahun ini cukup jauh berbeda yaitu $81,82 \%$ tergolong ke dalam usia reproduksi sehat (20-35 tahun), 7,80\% berusia $<20$ tahun, dan 10,39\% lainnya berusia $>35$ tahun, dengan tingkat pendidikan terbanyak lulusan SLTA $(48,05 \%)$, dan mayoritas responden tidak bekerja $(83,12 \%)$

Tabel 1.Distribusi Frekuensi Karakteristik Ibu Hamil di Wilayah Kerja Puskesmas Jatinangor, Kab. Sumedang Tahun 2018Karakteristik Respondenf $\%$ Usia reproduksi sehat

\begin{tabular}{lcc}
\hline Karakteristik Responden & $\mathbf{f}$ & $\mathbf{\%}$ \\
\hline Usia reproduksi sehat & & \\
$<20$ tahun & 6 & 7,80 \\
20-35 tahun & 63 & 81,81 \\
$>35$ tahun & 8 & 10,39 \\
\hline Pendidikan & & \\
SD & 7 & 9,10 \\
SLTP & 27 & 35,06 \\
SLTA & 37 & 48,05 \\
Perguruan Tinggi & 6 & 7,79 \\
\hline Pekerjaan & & \\
Bekerja & 13 & 16,88 \\
Tidak Bekerja & 64 & 83,12 \\
\hline Total & $\mathbf{7 7}$ & $\mathbf{1 0 0}$ \\
\hline
\end{tabular}

B. Kepuasan secara Umum

Tingkat kepuasan Ibu hamil atas layanan konseling gizi oleh bidan, mayoritas ibu hamil yang dijadikan responden dikategorikan puas terhadap layanan konseling gizi yang diberikan, yaitu mencapai 68 orang $(88,31 \%)$, sedangkan ibu hamil yang dikategorikan tidak puas sebanyak 9 orang $(11,69 \%)$.

Tabel 2.Distribusi Frekuensi Tingkat Kepuasan

Ibu Hamil atas Layanan Konseling Gizi oleh

Bidan secara Umum di Wilayah Kerja Puskesmas Jatinangor, Kab. Sumedang Tahun 2018

\begin{tabular}{lll}
\hline \multicolumn{1}{c}{ Tingkat Kepuasan } & \multicolumn{1}{c}{ f } & \multicolumn{1}{c}{$\%$} \\
\hline Puas & 68 & 88,31 \\
Tidak Puas & 9 & 11,69 \\
\hline Total & 77 & 100 \\
\hline
\end{tabular}

C. Tingkat Kepuasan terhadap Keseluruhan Dimensi Kualitas Pelayanan

Tingkat kepuasan rata-rata keseluruhan dimensi pelayanan konseling gizi yaitu 89,61\%. Dimensi pelayanan yang memiliki tingkat kesesuaian di bawah rata-rata yaitu dimensi keberwujudan (48,05\%).
Tabel 3.Distribusi Frekuensi Tingkat Kepuasan Ibu Hamil atas Layanan Konseling Gizi oleh Bidan Berdasarkan Dimensi Kepuasan di Wilayah Kerja Puskesmas Jatinangor, Kab. Sumedang Tahun 2018

\begin{tabular}{|c|c|c|}
\hline Dimensi Kepuasan & $\mathbf{f}$ & $\%$ \\
\hline \multicolumn{3}{|l|}{ Keandalan (Reabillithy) } \\
\hline Puas & 77 & 100 \\
\hline Tidak Puas & 0 & 0 \\
\hline \multicolumn{3}{|l|}{$\begin{array}{l}\text { Tanggung Jawab } \\
\text { (Responsiveness) }\end{array}$} \\
\hline Puas & 77 & 100 \\
\hline Tidak Puas & 0 & 0 \\
\hline \multicolumn{3}{|l|}{ Kepastian(Assurance) } \\
\hline Puas & 77 & 100 \\
\hline Tidak Puas & 0 & 0 \\
\hline \multicolumn{3}{|l|}{ Empati (Empathy) } \\
\hline Puas & 77 & 100 \\
\hline Tidak Puas & 0 & 0 \\
\hline \multicolumn{3}{|l|}{ Keberwujudan (Tangibles) } \\
\hline Puas & 37 & 48,05 \\
\hline Tidak Puas & 40 & 51,95 \\
\hline Kepuasan rata-rata & \multicolumn{2}{|c|}{$89,61 \%$} \\
\hline
\end{tabular}

Tingginya tingkat kepuasan ibu hamil pada dimensi reliability dikarenakan bidan yang dianggap andal dalam memberikan asuhan berupa konseling gizi, dimana bidan dapat memberikan asuhan yang cepat, tepat, dan memberikan informasi sesuai yang dibutuhkan oleh pasien.

Bidan juga mampu memberikan asuhan yang tanggap terhadap pertanyaan atau permasalahan ibu hamil. Responsiveness ini merupakan kemauan dari pemberi layanan untuk membantu pasien dalam secara cepat dan tepat dengan mendengarkan keluhan pasien dalam memberikan pelayanan.

Tingginya tingkat kepuasan pada dimensi assurance juga dapat dikarenakan oleh bidan yang dapat memerhatikan kebutuhan dan hak pasien, bidan yang sebelumnya diberikan pelatihan konseling gizi ini memiliki pengetahuan yang lebih tinggi terkait pemenuhan kebutuhan nutrisi selama keh a milan, sehing a mam pu mempertanggungjawabkan asuhan yang diberikan. Susanti dalam (Simbolon \& Siringoringo, 2017) menyebutkan bahwa untuk meningkatkan kualitas pelayanan kesehatan, pemberi layanan perlu diberikan pelatihan 
sehingga motivasinya dalam pemberian asuhan meningkat.

Bidan juga dianggap komunikatif dan memiliki rasa kepedulian yang tinggi terhadap ibu hamil, melihat tingkat kepuasan ibu yang tinggi pada dimensi emphaty. Nursalam dalam (Simbolon \& Siringo-ringo, 2017) menjelaskan bahwa emphaty merupakan ketersediaan pemberi layanan untuk memberikan perhatian secara pribadi kepada pasien.

Rendahnya tingkat kepuasan ibu hamil pada dimensi tangible menunjukkan bahwa pelayanan yang diberikan oleh bidan sebagai konselor belum sesuai dengan standar operasional yang berlaku dengan menggunakan fasilitas dan peralatan yang sesuai dengan kebutuhan pasien, dimana menurut Parasuraman dalam (Simbolon \& Siringo-ringo, 2017) bahwa tangible sendiridapat berupa penampilan fasilitas fisik dan peralatan materi komunikasi yang menarik.

Rendahnya kepuasan pada dimensi ini dipengaruhi oleh faktor usia, dimana $85,71 \%$ diantara responden yang dikategorikan tidak puas pada dimensi pelayanan keberwujuan adalah responden dengan rentan usia 20-35 tahun. Umur yang semakin tua mempunyai tingkat sensitifitas yang semakin tinggi pula, oleh karena itu perlu pelayanan yang lebih berkualitas yang salah satunya adalah menyediakan sarana dan prasarana yang lebih berkualitas (Eninurkhayatun, Suryoputro, \& Fatmasari, 2017)

D. Frekuensi Karakteristik Responden terhadap Kepuasan secara Umum Tabel 4.Hubungan Karakteristik Ibu Hamil dengan Tingkat Kepuasan Konseling Gizi di Wilayah Kerja Puskesmas Jatinangor, Kab. Sumedang Tahun 2018

\begin{tabular}{lll}
\hline \multirow{2}{*}{ Karakteristik } & \multicolumn{2}{c}{ Kepuasan } \\
\cline { 2 - 3 } & Puas n(\%) & $\begin{array}{c}\text { Tidak Puas } \\
\mathbf{n}(\%)\end{array}$ \\
\hline Pekerjaan & & \\
\hline Bekerja & $13(100)$ & $0(0)$ \\
Tidak Bekerja & $55(85,9)$ & $9(14,1)$ \\
\hline Total & $\mathbf{6 8 ( 8 8 , 3 )}$ & $\mathbf{9 ( 1 1 , 7 )}$ \\
\hline
\end{tabular}

Tabel 4.Hubungan Karakteristik Ibu Hamil dengan Tingkat Kepuasan Konseling Gizi di Wilayah Kerja Puskesmas Jatinangor, Kab. Sumedang Tahun 2018 (Lanjutan...)

\begin{tabular}{lll}
\hline \multirow{2}{*}{ Karakteristik } & \multicolumn{2}{c}{ Kepuasan } \\
\cline { 2 - 3 } & \multicolumn{1}{c}{ Puas n(\%) } & $\begin{array}{c}\text { Tidak Puas } \\
\mathbf{n}(\%)\end{array}$ \\
\hline Usia Reproduktif & & \\
\hline$<20$ tahun & $5(83,3)$ & $1(16,7)$ \\
\hline $20-35$ tahun & $7(87,5)$ & $1(12,5)$ \\
\hline$>35$ tahun & $56(88,9)$ & $7(11,1)$ \\
\hline Total & $\mathbf{6 8 ( 8 8 , 3 )}$ & $\mathbf{9 ( 1 1 , 7 )}$ \\
\hline Pendidikan & & \\
\hline SD & $6(85,7)$ & $1(14,3)$ \\
\hline SLTP & $24(88,9)$ & $3(11,1)$ \\
\hline SLTA & $32(86,5)$ & $5(13,5)$ \\
\hline Perguruan Tinggi & $6(100)$ & $0(0)$ \\
\hline Total & $\mathbf{6 8 ( 8 8 , 3 )}$ & $\mathbf{9 ( 1 1 , 7 )}$ \\
\hline
\end{tabular}

Frekuensi dari setiap karakteristik responden terhadap kepuasan secara umum, dimana berdasarkan pekerjaan, mayoritas ibu yang tidak bekerja dikategorikan tidak puas terhadap pelayanan konseling gizi $(14,1 \%)$. Hasil penelitian (Eninurkhayatun et al., 2017) menunjukkan tidak ada hubungan status pekerjaan dengan tingkat kepuasan, hal ini sejalan dengan penelitian (Hidayati, 2013)

Tidak hanya itu, berdasarkan usia reproduksi, ibu dengan usia $<20$ tahun $16,7 \%$ tidak puas terhadap pelayanan konseling gizi. Menurut Jacobalis dalam (Mulyani, 2014) mengatakan bahwa umur dan jenis kelamin merupakan salah satu faktor yang mempengaruhi persepsi terhadap mutu pelayanan kesehatan. Dimana pada penelitian ini, umur yang lebih tua (>20 tahun) memiliki kepuasan yang tinggi terhadap pelayanan konseling gizi dibandingkan dengan kelompok umuryang lebih muda.

Dilihat dari aspek pendidikan terakhir, ibu dengan pendidikan SD mayoritas juga juga tidak puas terhadap pelayanan konseling gizi yang diberikan oleh bidan (14,3\%). Menurut Jacobalis dalam (Mulyani, 2014) juga mengatakan bahwa pendidikan juga dapat mempengaruhi pola pikir rasional dan irasional seseorang dalam mengambil keputusan, menggunakan dan atau memanfaatkan pelayanan kesehatan.

Responden yang didominasi berlatar 
belakang pendidikan rendah (SD/SMP) memiliki kecenderungan inkonsisten persepsi yang tinggi (tidak tetap pendirian), mudah dipengaruhi dibandingkan dengan responden yang berpendidikan lebih tinggi.

\section{PENUTUP}

Karakteristik responden dalam penelitian ini terbagi berdasarkan pekerjaan, usia dan pendidikan terakhir. Berdasarkan usia reproduksi $82 \%$ ibu hamil tergolong ke dalam usia reproduksi sehat (20-35 tahun) persentase kepuasan $70,13 \%$, dengan tingkat pendidikan terbanyak lulusan SLTA (48,05\%) persentase kepuasan 41,56\%, dan mayoritas responden tidak bekerja $(83,12 \%)$ dengan persentase kepuasan $71,43 \%$.

Sebanyak $88,31 \%$ responden dikategorikan puas terhadap layanan konseling gizi yang diberikan oleh bidan secara umum. Dari nilai kepuasan, dimensi keberwujudan dan saran prasarana yang ada (tangibles) memiliki nilai di bawah rata-rata, dimana 51,95\% responden pada dimensi ini tergolong tidak puas dengan pelayanan konseling gizi yang diberikan.

Untuk konseling gizi ini sebaiknya dilakukan secara teratur setiap kunjungan antenatal care oleh tenaga kesehatan untuk meningkatkan pengetahuan dan sikap ibu tentang kebutuhan nutrisi selama kehamilannya. Pengadaan konseling gizi pun diharapkan dengan memperhatikan kelima dimensi mutu untuk meningkatkan kepuasan pasien, khususnya pada dimensi tangibles yang masih berada di bawah rata-rata kepuasan responden pada penelitian ini.

\section{DAFTAR PUSTAKA}

Amalia, L., Permatasari, I. I., Ali Khomsan, H. R., Herawati, T., \& Nurdiani, R. (2015). Pengetahuan, Sikap, dan Praktek Gizi Ibu Terkait Iodium dan Pemilihan Jenis Garam Rumah Tangga di Wilayah Pegunungan Cianjur. Jurnal Gizi Dan $P$ a $n g a n$, 10 ( 2 ). https://doi.org/http://dx.doi.org/10.25182 /jgp.2015.10.2.\%25p

Azzahra, M. F., \& Muniroh, L. (2015). Pengaruh Konseling terhadap Pengetahuan dan Sikap Pemberian ASI. Media Gizi Indonesia, $\quad 10(1)$. https://doi.org/http://dx.doi.org/10.20473 /mgi.v10i1.20-25

Depkes. (2007). Laporan Hasil Riset Kesehatan Dasar Provinsi Jawa Barat Tahun 2007. Bandung.

Dinas Kesehatan Sumedang. (2017). Profil Kesehatan Kabupaten Sumedang 2017. Jawa Barat: Dinas Kesehatan Kabupaten Sumedang.

Eninurkhayatun, B., Suryoputro, A., \& Fatmasari, E. Y. (2017). Analisis Tingkat Kepuasan Pasien terhadap Kualitas Pelayanan Rawat Jalan di Puskesmas Duren dan Puskesmas Bergas Kabupaten Semarang Tahun 2017. Jurnal Kesehatan Masayarakat, 5(4), 33-42.

Hidayati, A. N. (2013). Analisis Hubungan Karakteristik Pasien Dengan Kepuasan Pelayanan Rawat Jalan Semarang Eye Center (SEC) Rumah Sakit Islam Sultan Agung Semarang. Jurnal Kesehatan Masyarakat. Universitas Diponegoro. Retrieved from http://eprints.undip.ac.id/41192/

I, S., Kullen, Burdon, \& H, O. (2014). Relationship Between Nutrition Knowledge and Dietary Intake. The British Journal of Nutrition, 111(10). https://doi.org/10.1017/S00071145140000 87

Kementerian Kesehatan, R. I. (2013). Hasil Riset Kesehatan Dasar 2013. Jakarta.

Kurniawan, A., \& Intiasari, A. D. (2012). Pengaruh Karakteristik Pasien terhadap Indeks Kepuasan Masyarakat tentang Pelayanan Rawat Jalan Puskesmas Banyumas. Jurnal Kesmasindo, 5(2), 169-179. Re tri e ved from http://jos.unsoed.ac.id/index.php/kesma sindo/article/view/43/41

Mariana, W., \& Khafidhoh, N. (2013). Hubungan Status Gizi dengan Kejadian Anemia pada Remaja Putri di SMK 
Swadaya Wilayah Kerja Puskesmas Karangdoro Kota Semarang Tahun 2013. Jurnal Kebidanan, 2 (4). https://doi.org/http://dx.doi.org/10.31983 jjkb.v2i4.98

Mulyani, R. (2014). Hubungan Karakteristik Pasien dengan Kepuasan Pelayanan Gizi di Ruang Rawat Inap. Jurnal Keperawatan, $X(2), 231-239$.

Prawita, A., Susanti, A. I., \& Sari, P. (2017). Survei Intervensi Ibu Hamil Kurang Energi Kronik (KEK) di Kecamatan Jatinangor Tahun 2015. Jurnal Sistem Kesehatan, 2(4).

Purandare, C. N. (2012). Maternal Nutritional Deficiencies and Interventions. Journal of Obstetrics \& Gynecology of India, 62(6), 621-623. https://doi.org/10.1007/s13224013-0347-9

Simbolon, P., \& Siringo-ringo, M. (2017). Kepuasan Pasien Imobilisasi dalam Pemenuhan Personal Hygiene Rumah Sakit santa Elisabeth Medan. Jurnal Kesehatan Vokasional, 2(2). https://doi.org/https://doi.org/10.22146/j kesvo.30335

Sudikno, S., \& Sandjaja, S. (2016). Prevalensi dan Faktor Risiko Anemia Pada Wanita Usia Subur di Rumah Tangga Miskin di Kabupaten Tasikmalaya dan Ciamis,
Provinsi Jawa Barat. Indonesian Journal of Reproductive Health, 7(2). Retrieved from http://ejournal.litbang.depkes.go.id/inde x.php/kespro/article/view/4909

Sulastijah, S., DW, S., \& Helmyati, S. (2015). Pengaruh Pendidikan Gizi Dalam Upaya Meningkatkan Kepatuhan Konsumsi Zat Besi Melalui Kelas Ibu Hamil. Jurnal Gizi Klinik Indonesia, 12 (2). https://doi.org/https://doi.org/10.22146/ij cn.23125

Susanti, A. I., Sahiratmadja, E., Winarno, G., Sugianli, A. K., Susanto, H., \& Panigoro, R. (2017). Low Hemoglobin among Pregnant Women in Midwives Practice of Primary Health Care, Jatinangor, Indonesia: Iron Deficiency Anemia or $\beta$ Thalassemia Trait? Anemia. https://doi.org/https://doi.org/10.1155/20 $17 / 6935648$

United Nations. (2015). Sustainable Development Goals. Retrieved from https://www.un.org/sustainabledevelop ment/sustainable-development-goals/

Utama, S. (2003). Memahami Fenomena Kepuasan Pasien Rumah Sakit. Universitas Sumatera Utara.

WHO. (2012). Daily Iron and Folic Acid Supplement in pregnant Women.

WHO. (2016). Maternal Death. 